\title{
WAGERING WITH AND WITHOUT PASCAL
}

\author{
Joseph Anderson and Daniel Collette
}

\begin{abstract}
Pascal's wager has received the attention of philosophers for centuries. Most of its criticisms arise from how the wager is often framed. We present Pascal's wager three ways: in isolation from any further apologetic arguments, as leading toward a regimen intended to produce belief, and finally embedded in a larger apology that includes evidence for Christianity. We find that none of the common objections apply when the wager is presented as part of Pascal's larger project. Pascal's wager is a successful argument in its proper place. However, the most interesting features of our first two presentations of the wager turn out to be either irrelevant or missing from our reading: infinite utility and the relativity of evidence. The successful wager is a boring wager. Still, this study shows us how the wager might profitably be incorporated into different apologetic contexts and why it often can't.
\end{abstract}

\section{Pascal's Wager Served Three Ways}

It is a testament to Pascal's genius that the wager continues to keep the attention of philosophers hundreds of years after his death, despite the incomplete and unorganized state of the text of the Pensées. Unfortunately for Pascal, much of the attention the wager receives is critical; and, while Pascal's wager is repeatedly taught in undergraduate philosophy classrooms, hardly any attention is paid to the Pensées beyond the few pages in which the wager is presented. ${ }^{1}$ In this article, we present Pascal's wager three ways: first in isolation from any further apologetic arguments, second as leading toward a regimen intended to produce belief, and finally embedded in a larger apology that includes some evidence for Christianity. What we find is that none of the common objections to the wager apply in the context of Pascal's larger apologetic project. Pascal's wager is a successful argument in its proper place. However, the most interesting features of the first two presentations of the wager examined here-infinite utility and the relativity of evidence-turn out to be either irrelevant or missing from our reading of Pascal. The successful wager is a boring wager. Still, this study

\footnotetext{
${ }^{1}$ Hunter 2013 is one recent exception.
} 
shows us how the wager might profitably be incorporated into different apologetic contexts and why it often can't.

\section{The Isolated Wager}

Most frequently, the wager is presented as a stand-alone argument that suggests that we can compensate for our lack of knowledge of God's existence by thinking about the utility of belief.

[E]ither God is or he is not. But to which side shall we incline? Reason can determine nothing here. There is an infinite chaos that separates us. At the extremity of this infinite distance, a game is being played in which heads or tails will turn up. How will you wager? You have no rational grounds for choosing either way or for rejecting either alternative. [ . . . ] Since you must choose, let us see what is the less profitable option. You have two things to lose, the true and the good; and two things to stake, your reason and your will, your knowledge and your beatitude; and your nature has two things to avoid, error and wretchedness. Since you must choose, your reason is no more offended by choosing one rather than the other. This settles one point. But your beatitude? Let us weigh the gain and the loss in calling heads that God exists. $\left(\right.$ S680/L418) ${ }^{2}$

In our ignorance of the true, we turn to the good. As it turns out, belief in God has the potential to win us "an eternity of life and happiness," "an infinite life of infinite happiness" (S680/L418). Now, we don't know whether there is a God, and we're not even exactly sure what odds to assign to the existence of God. While we are unsure of the odds of winning this prize, it turns out that it doesn't matter what the odds are. As long as there is some non-zero chance that God exists and as long as no other outcome offers infinite rewards, practical reason requires that we bet that God exists. ${ }^{3}$ The infinite expected utility of this strategy renders all other strategies irrational. Pascal presents this point as follows:

But here there is an infinite life of infinite happiness to be won, there is one chance of winning against a finite number of chances of losing, and what you are staking is finite. There's no decision left wherever there is an infinity

\footnotetext{
${ }^{2}$ Translations of the Pensées are from Pascal 2005 unless otherwise noted. Citations are to the fragment numberings by Sellier (S) and LaFuma (L), which are provided in Pascal 2005. When the French text is cited or provided, we use Pascal 2011, and provide only the Sellier numbering.

${ }^{3}$ Alan Hájek's presentation of the argument $(2003,27-29)$ brings out the impact of infinite utilities and the strength of the conclusion quite well.
} 
and wherever there is not an infinite number of chances of losing against the chance of winning. There is no time to hesitate; you must give everything [il faut tout donner]. (S680/L418) ${ }^{4}$

While we don't know how many chances of losing we have, any finite number we plug in leaves our conclusion untouched. We should bet our lives to have a chance of infinite rewards.

While Pascal's practical approach and his argument have a certain intuitive appeal, there are a number of powerful objections that quite effectively undermine it. Five of these objections will be discussed here.

\subsection{Many-Gods Objection}

First, the many-gods objection has been raised since Diderot and has taken many different forms. Pascal's wager is about whether we should believe in the Christian God. ${ }^{5}$ It assigns an infinite expected utility to the strategy of believing in the Christian God, but we all know that there are a number of different religions, some of which offer infinite rewards for various actions and beliefs. Some of the paths to eternal blessedness offered by these religions are mutually exclusive. One cannot believe that Jesus is God and that Jesus is not God at the same time, for instance. Further, there are possible belief systems that are not instantiated by any actual religion which include infinite rewards for disbelieving in God; that is, God would reward everyone except those who wagered. So, while it makes sense to wager in favor of the possibility of infinite rewards in the face of our uncertainty, there are many tables in our Pascalian casino offering such a bet. The wager offers no guidance regarding which path to infinite blessedness one should bet on. ${ }^{6}$

\footnotetext{
4 "mais il y a ici une infinité de vie infiniment heureuse à gagner, un hasard de gain contre un nombre fini de hasards de perte, et ce que vois jouez est fini. Cela ôte tout parti: partout où est l'infini et où il n'y a pas infinité de hasards de perte contre celui de gain, il n'y a point à balancer, il faut tout donner." (S680) Ariew translates the phrase 'Cela ote tout parti' more colloquially as 'All bets are off.' We opted for the more literal, "There's no decision left." Either way, the point being expressed is one of moral necessity-in the face of infinity, the odds are so heavily in one's favor, that it's almost as if there were no longer a choice; to refuse to affirm at this point would be to act so irrationally that it's as if there were no other choice. ${ }^{5}$ Jeff Jordan (2006) provides a very helpful survey of different forms of the wager in Pascal and related writings (16-25). He writes of these, "Pascal intended the Wagers as arguments for the rationality of theistic belief, and not as arguments for the rationality of Christian belief" $(8-9)$. If this is the case, then it is not clear where Pascal would be getting his assumptions about the rewards and punishments associated with belief.

${ }^{6}$ For additional commentary on the many-gods objection, see Hunter 2013, 125-129.
} 


\subsection{Moral Objection}

This objection, first seen in Voltaire, has several articulations, but their common criticism is against the morality of the wager. ${ }^{7}$ William James (1956) famously describes Pascal as attempting to strong-arm the unbeliever into belief, a "last desperate snatch at a weapon against the hardness of the unbelieving heart" (10-11). The concern here is whether the unbeliever who accepts the wager has genuine faith. According to some, belief through a mechanism such as the wager is not only silly, but vile; it ignores the sciences and all of their potential to discover and convince, all while reducing belief down to a base subjectivism grounded in one's private dreams.

James himself believes that our non-intellectual nature influences our convictions, and accordingly does not see his reading of the wager as a problem. But it is easy to see why James's observations have become fodder to criticize Pascal, framing them as a moral objection. Here the wager is morally unforgivable as it asks us to believe what we have no reason to believe: if a belief is accepted on insufficient evidence then it is, in Clifford's words, a stolen pleasure (James 1956, 11-12). Believing in God for such mercenary motives is immoral and should not attract the favor of a perfect being.

\subsection{Evidentialist and Intellectualist Objections}

Some instances of the moral argument are framed within strong evidentialism or intellectualism, although these objections can be presented without explicit moral connotations. The concerns expressed by W. K. Clifford (1999) are that one has a moral obligation not to hold beliefs without evidence and not to hold beliefs more strongly than is warranted by the strength of the evidence. Since the reasons for belief offered by the wager are prudential rather than evidential, one ought not to believe in theism based on the wager.

It has further been suggested that humans can't form beliefs for purely prudential reasons even if it was acceptable for us to do so. Recognizing that it would be prudent to believe is insufficient for the generation of a belief. If this intellectualist objection is correct, then even if the wager's logic is impeccable, it wouldn't matter. We could acknowledge that it would be wise to believe in God and nevertheless be incapable of believing in God without evidence.

\subsection{Mixed-Strategies Objection}

Building on the work of Antony Duff (1986), Alan Hájek (2003) has argued that the infinite expected utility in the wager can actually be found in every action we take. Since the expected utility of a strategy is calculated by

\footnotetext{
${ }^{7}$ For examples of other moral objections, see Quinn 1994, 62-67 and Jordan 2006, 127-133.
} 
multiplying the payoff and the probability of receiving that payoff, far more strategies have infinite utility than either Pascal or even proponents of the many-gods objection have realized. Suppose you are convinced by the wager and are about to start believing in God. You don't know what the odds of receiving blessedness are, but that doesn't matter. Since the potential payoff is infinite, the expected utility of believing is infinite. Now, Hájek suggests that you consider some other strategies. Instead of believing in God, flip a coin. If it comes up heads, believe in God; otherwise, don't. The odds of this strategy paying off are half of whatever the odds of straightforwardly believing in God, but because the payoff would be infinite in either case, the expected utility for both is infinite. This is what Hájek calls a mixed strategy (31).

If this is bad for Pascal's wager, it only gets worse. Hájek (2003) writes,

For isn't anything that an agent might choose to do really a mixed strategy between wagering for and wagering against God, for some appropriate (rational subjective) probability weights? For whatever one does, one should assign some positive probability to winding up wagering for God. Even if you are currently an atheist, dear reader, you should assign positive probability to your wagering for God by the time you reach the end of this sentence [ . . . . In fact, I would hazard to say [... ] that every rational agent's life is a constant series of such 'gambles,' with wagering for God as one of the outcomes. The probability of ending up wagering for God should be positive even for those who single-mindedly do all they can to wager against God-by practicing devil worship, say. The point generalizes to any course of action. By Pascal's lights, for every rational agent, every action has maximal expected utility. (31)

Hájek finds that any attempt to save the wager will fail, since the rewards offered should be such that adding anything to them leaves the value unchanged (reflexivity under addition), but can't be such that multiplying them by just any positive probability leaves the value unchanged (reflexivity under multiplication), which is impossible (47-8).

The objection from mixed strategies seems to be a sophism. Suppose that the reason salvation has an infinite utility is largely due to the unending duration of the afterlife. Consider an afterlife of 10,000 good years. Obviously, because the utility here is finite, there are some positive probabilities that aren't high enough to warrant wagering. And clearly, objections to the standard wager would apply for a large but finite afterlife as well. But what we want to point out is that mixed strategies are far inferior to straightforward belief in this case. Flipping a coin would give us an expected utility of half the expected utility of straightforwardly believing. And the same is the case for an afterlife of 10,001 good years, 10,002 good years, and so on. 
As the duration of the afterlife increases, the expected utility of wagering increases. Can it really be the case that it is always a bad idea to lower the chances of receiving the reward unless the reward is infinite? The fact that the blessed life we're wagering for doesn't end should not justify us taking strategies that lower the probability of receiving that blessed life.

\subsection{Evaluation}

The isolated wager is exactly the kind of argument many philosophers love to teach: terribly interesting and highly objectionable. It has an initial appeal that all but disappears in the face of these objections.

\section{The Partially Embedded Wager}

While many of these objections seem quite strong, one can find resources within Pascal's work for responding to them. Daniel Garber $(2007 ; 2009)$ has drawn attention to another aspect of Pascal's project that Garber calls the Pascal regimen. Pascal's Jansenism raises concerns that are practically identical to those raised by the intellectualist objection-salvation and indeed saving faith is a gift from God, and so it cannot simply be the result of our recognizing the utility of belief. Given Pascal's deep commitment to Jansenism, it would be a surprise if he didn't have something to say that could help us with the intellectualist objection. As Garber points out, Pascal does not disappoint.

\subsection{Wager and Regimen}

After walking his imagined libertine interlocutor through the wager, the libertine's response isn't faith but frustration: "Yes, but my hands are tied and my mouth is shut; I am forced to wager, and am not free. I have not been released and I am made in such a way that I cannot believe. What, then, would you have me do?" (S680/L418). The answer is the regimen. Pascal writes,

You would like to find faith and do not know the way?

You would like to be cured of unbelief and ask for the remedies? Learn from those who were bound like you, and who now wager all they have. These are people who know the way you wish to follow and who are cured of illness of which you to be cured. Follow the way by which they began: they acted as if they believed, took holy water, had masses said, etc. This will make you believe naturally and mechanically [abêtira]. $\left(\right.$ S680/L418) ${ }^{8}$

\footnotetext{
${ }^{8}$ Translated literally, abêtir means to make stupid or beastly. In other fragments, Pascal highlights the machine-like capacities of beasts, such as, when the parrot wipes its beak mechanically: 'Le bec du perroquet, qu'il essuie quoiqu'il soit net.' ['The parrot's beak, which
} 
What happens after the wager isn't belief by simple force of will but a process that helps one form genuine belief.

How does the regimen help one develop genuine faith? Our reading will dispute this, but, according to Garber, the libertine discovers evidence for the existence of God that she could not discover before. "Pascal's God doesn't ask for a blind faith," Garber (2009) writes, "it is a faith supported by reasons. But these reasons can only be appreciated after I am in a particular state of mind: only after I am committed to him, in a way, after I have already dedicated myself to the search for God, only after God has moved my heart" (17). For Garber's Pascal, the reasonableness of theism depends on one's situation. The wager convinces the libertine to put herself in a situation from which theism appears reasonable.

Garber offers textual support for his reading (16-17) with the following passages:

Thus wanting to appear openly to those who seek him with all their heart and hidden from those who flee him with all their heart, God has tempered the knowledge of himself by giving signs of himself that are visible to those who seek him, and not by those who do not seek him.

There is enough light for those who desire only to see and enough darkness for those of a contrary disposition. (S182/L149)

'Why, do you not yourself say that the sky and the birds prove God?' No. 'And does not your religion say so?' No. For while this is true in a sense for some souls to whom God gave this illumination, nevertheless it is false for most of them. (S38/L3)

These passages indicate that whether one finds evidence (or maybe even proof) of God's existence depends on that person's desires.

In summary, this interpretation of Pascal's wager and its role in convincing the reader follows this pattern: the wager convinces the reader to seek God not by seeking evidence but by changing one's situation. Then, desiring to believe, surrounded by believers, and participating with them in

it wipes although it is clean.'] (S139/L107). We are thus in favor of the sense implied by Ariew and Krailsheimer, the latter writing in a footnote, "That is, the unbeliever will act unthinkingly and mechanically, and in this become more like the beasts, from whom man was differentiated, according to contemporary philosophy, by his faculty of reason" (Pascal 1995, 30n57). Likewise, Ariew writes, "Man is in part a beast or machine, and one needs to allow that part its proper function" (Pascal 2005, 214n2). For Pascal, both the intellect and the will must be moved. See also S45/L11 and S59/L25. For more on this controversy, see Hunter 2013, 139-142.

${ }^{9}$ Thomas V. Morris holds a similar position, claiming, "It seems to have been Pascal's conviction that a person's epistemic condition with respect to theism and atheism is a function of his attitudes, desires, and other commitments, and that in turn these are a function of the sorts of patterns of behavior he liked to call 'habit'” $(1986,451)$. 
rituals, this person finds evidence for God's existence that was previously unavailable.

\subsection{Objections}

When we pair the wager with the regimen and the evidence that is supposed to come with it, we find some noteworthy developments against some of the common objections reviewed above. If the mixed-strategies objection works for the isolated wager, then it works here, too. But how the many-gods objection fares is a bit more complicated. Since the outcome of regimen is a belief based on evidence, it is hard to imagine that the moral, evidentialist, or intellectualist objections can get any traction. It also seems at first that the many-gods objection would not pose any problems. The outcome is evidence for the religion associated with the regimen and not others. But presumably one could have undergone any number of regimens and found evidence for any number of religions, although it seems that this rules out uninstantiated religions.

Garber offers several examples of the regimen being applied to other beliefs besides Christianity. The most interesting of them is recorded in T. M. Luhrmann's Persuasions of the Witch's Craft: Ritual Magic in Contemporary England (1989). In Luhrmann's case (as cited in Garber 2009), she entered into occult worlds to study why so many apparently intelligent, well-educated professionals were actively engaged in the occult and magical world. She found that by undergoing an occult regimenattending their meetings, reading their literature, and participating in occult rites and rituals-she began to believe herself that she was seeing druids, feeling magical power flow through her body, and feeling a strong sense that the ancient gods were real. If different regimens can lead to different beliefs, Garber finds that the many-gods objection comes back in nearly full force, now restricted to actually existing belief systems promising infinite rewards.

Garber raises a further objection based on the situation-dependency of evidence. The odds of self-deception are tremendously high. It is true that once one accepts the wager and decides to undertake a regimen that one will likely believe. The problem is not that the wager is ineffective; the problem is that it works too well-so well that it may be a case of voluntary brainwashing. Garber (2007) writes,

Even when I try to imagine what it is like to be a believer [without undergoing a regimen], the reasons that Pascal says move a believer don't move me. If they did, then I wouldn't have to go through the motions the way Pascal says I must in order to attain the state of belief that I seek. If they did, then my conversion would be rational, the way the conversion from the Ptolemaic universe to the Copernican is. But it isn't. I may know that if I subject myself to 
a certain regimen (i.e., engage in religious practices), then eventually I will attain a state in which I will believe in God, and I will believe that my belief is rational. But that isn't good enough. From my present point of view, it looks too much like intentional self-delusion. (39)

This interpretation of the wager makes evidence inscrutable from the outside. Because of this, without undergoing the regimen ourselves, we have every reason to be skeptical about the reasonableness of the belief that would be generated by it. Even if we did undergo the regimen and attain the reasons Pascal seems to be speaking of, it would be right of us to wonder about the veracity and the reasonableness of our belief given that similar regimens might very well have given us similar reasons for contradictory beliefs.

\section{The Embedded Wager}

We have seen that reading beyond the wager helps us to avoid some of the common objections to the wager. But by giving attention to another component of the Pensées-proofs of the Christian religion-a reading of the wager and its place in Pascal's apology emerges that avoids all the common objections. What we find is that evidence comes before the wager, not after. To make this case, we will have to provide another interpretation of the role of the regimen as well as the skeptical language in the wager and other places in the Pensées.

\subsection{Order}

A clarification is in order. When we claim that evidence precedes the wager in the Pensées, we do not mean to suggest that a completed edition of Pascal's apology must place evidence prior to the wager chronologically in the text. There is some debate about where the wager would appear had Pascal completed the work. William David Wetsel (2009) suggests of the wager, "standing as the opening chapter after the preface, its only purpose is to fascinate the reader and lure him into reading further into Pascal's Apology" (133). It may be that the wager would have occurred prior to the evidences, but nevertheless the former depends on the latter. In the order of reasons, one has to have some reason to think that God would reward belief prior to accepting the wager, as many objectors have pointed out. What is rarely noticed is that Pascal provides some (to his own satisfaction). ${ }^{10}$

Further, there is evidence in the wager fragment itself that Pascal has in mind that his interlocutor already be aware of at least some of these

\footnotetext{
${ }^{10}$ While most work on the wager completely ignores these arguments, there are two noteworthy exceptions: Fouke 1989 and Morris 1986, 442-444.
} 
evidences. "II confess, I admit it. But still . . . Is there no means of seeing what is in the cards?' Yes, Scripture and the rest, etc." (S680/L418). This line is significant. Not only does it imply that the wager fragment isn't intended to stand alone, but, as will be further explained below, it even indicates that it need not rely on infinite utility to make the probability of God's existence irrelevant. ${ }^{11}$

\subsection{Pascal's Proofs}

Much of the Pensées is devoted to providing evidence for Christianity. While most readers of the wager take for granted that Pascal is trying to motivate belief without evidence, he explicitly claims otherwise:

I [God] do not intend you to submit your belief to me without reason, and I do not claim to subdue you by tyranny. I also do not claim to give you a reason for everything. To reconcile these oppositions, I intend to make you see clearly by convincing proofs, by marks of the divine in me that will convince you of what I am; and to establish my authority by marvels and proofs you cannot reject. $\left(\right.$ S182/L149) ${ }^{12}$

While Pascal does not believe Christianity can be demonstrated, he clearly has a place for proofs of some kind. ${ }^{13}$

We will look at three examples of Pascal's proofs, but first we need to understand what Pascal has in mind. If he thinks there are no demonstrations of Christianity and indeed that "Reason can determine nothing here" (S680/L418), then what is he talking about when he talks about proofs?

We must <have these three qualities: sceptic, geometer, Christian. Submission. Doubt. And they fit together>

\footnotetext{
11 One might think that "Yes, Scripture and the rest, etc." is out of place since Pascal is speaking "according to our natural lights," as he states at the beginning of the wager fragment. If the entire wager argument is supposed to be conducted "according to our natural lights," then it would, perhaps, be inappropriate to bring in arguments from scripture. However, S182/L149 makes clear that Pascal doesn't simply distinguish faith from natural lights. Since Pascal makes clear that his religion is opposed to blind faith as much as it is to complete demonstration, it is possible to see appeals to scripture as falling within the realm of our natural lights, so long as they are not simply appeals to the authority of scripture. We will see that Pascal is interested in, among other things, fulfilled prophesies as evidence of the truth of the Christian religion. Whatever the merits of this evidence, it isn't an appeal to blind faith.

${ }^{12} \mathrm{Je}$ n'entends pas que vous soumettiez votre créance à moi sans raison, et ne prétends point vous assujettir avec tyrannie. Je ne prétends point aussi vous rendre raisons de toutes choses. Et pour accorder ces contrariétés, j'entends cous faire voir clairement pas des preuves convaincantes des marques divines en moi qui vous convainquent de ce que je suis, et m'attirer autorité par des merveilles et des preuves que vous ne puissiez refuser. (S182)

${ }^{13}$ In one opaque fragment Pascal writes, "Preuves de la religion. Morale./Doctrine./Miracles./Prophéties./Figures" (S21/L402). This is a list of proofs that he will offer as evidence of Christianity, reducible to two kinds: moral/existential and theological. We focus on only a few of these for the sake of brevity.
} 
know when to doubt, when to affirm, and when to submit. Whoever does not do so fails to understand the force of reason. There are some who fall short of these three principles, either by affirming everything is demonstrable, lacking knowledge about demonstration; or by doubting everything, lacking knowledge about when to submit; or by submitting to everything, lacking knowledge about when to judge. (S201/L170)

So, while God's existence cannot be demonstrated, reason still leads us to belief. "Reason would never submit, if it did not judge that there are occasions when it should submit" (S205/L174). These passages together with the proofs (discussed below) strongly suggest that Pascal thinks that reason leads us to believe in Christianity and not just for prudential reasons. It seems then that he sometimes talks about reason in a strict sense referring to demonstration, as in the wager fragment. But other times, he intends reason (or the force of reason in S201) in a weaker sense as including non-demonstrative proofs.

Pascal offers fulfilled prophecies as proof of Christianity. He writes:

I see many contrary religions, and so all of them false but one. Each of them wants to be believed on its own authority and threatens unbelievers. I do not therefore believe them on that account. Anyone can say this. Anyone can call himself a prophet. But I see Christianity, where I find prophecies, and this is not something anyone can do. (S230/L199)

It is worth pointing out that, given the prominence of the many-gods objection in many treatments of the wager, this fragment occurs in the context of a treatment of Islam. Pascal knows he needs to provide reasons for preferring Christianity to other religions. Of course, this evidence is rather weak. After all, that the old testament prophecies really point to Christ's birth is a rather contentious claim. It is easy to believe that they do if one already accepts that Christ is God incarnate and the focal point of God's redemptive plan; but if one doesn't already believe this, it is far from clear that the prophecies in Isaiah and the Psalms along with the reports of the birth, life, and death of Christ give us strong reasons to believe in Christianity.

As a second example, Pascal finds reason to prefer Christianity to other religions in the way it produces exactly the qualities prescribed by Pascal's analysis of the human condition. He writes:

Only the Christian religion has been able to cure these two vices [pride and apathy], not by using one to expel the other according to the wisdom of the world, but by expelling both through the simplicity of the Gospel. For it 
teaches the righteous, whom it exalts even to participation in divinity itself, that in this sublime state they still carry the source of all corruption, rendering them throughout their lives subject to error, wretchedness, death, and sin. And it proclaims to the greatest unbelievers that they are capable of their Redeemer's grace. So, having those it renders just tremble and consoling those it condemns, it tempers fear with hope so well through that double capacity common to all for grace and sin, that it humbles infinitely more than reason alone, but without despair. And it exalts infinitely more than natural pride, but without inflating us, making it evident in this way that, since it alone is exempt from error and vice, the duty of instructing and correcting men belongs to it alone. (S240/L208)

Any true religion, Pascal thinks, needs to acknowledge both our greatness and our wretchedness. It needs to exalt us while at the same time humbling us. Pascal judges that only Christianity is capable of this.

Finally, Pascal thinks the very reasonableness of seeking God and the foolishness of not seeking him gives evidence of his existence.

As for choosing sides, you must take the trouble to seek the truth, because if you die without worshiping the true principle, you are lost. 'But,' you say, 'if he had wanted me to worship him, he would have left me some signs of his will.' He has done so, but you neglect them. Seek them, then; it is well worth it. (S190/L158)

These are signs that we should seek God. The signs are that it is reasonable to seek God and foolish to remain diverted.

There are only three kinds of people: those who serve God, having found him; those who are busy seeking him, not having found him; those who live without seeking or finding him. The first are reasonable and happy, the last are foolish and unhappy; those in the middle are unhappy and reasonable. (S195/L163)

What makes those who don't seek foolish? The same considerations motivating the wager.

A man is in prison, not knowing whether his sentence has been passed, with only an hour to find out, this hour being sufficient to obtain its repeal if he knew that it had been passed. It would be unnatural if he spent the hour not finding out whether his sentence had been passed, but playing piquet. (S195/ L163) 
Pascal almost immediately continues by telling us that this is another proof of God, writing, "Thus, not only does the zeal of those who seek him prove God, but also the blindness of those who do not seek him" (S195/L163). How does this reasonableness and foolishness function as a proof? Christianity, once again, makes reasonable aspects of our human condition. You would expect that if there were a God, he would tell us that it was reasonable to seek him. And we find that just thinking about it for a moment reveals to us this reasonability. This kind of proof falls very short of a demonstration, but it does provide some weak hypothetico-deductive support. ${ }^{14}$

\subsection{Persuasion: Evidence, Wager, and Regimen}

Pascal offers what he takes to be evidence or convincing proofs that do not rise to the level of demonstrations. Where do these fit in his apology? As many commentators have pointed out, the wager is flawed if separated from any considerations that would have us prefer one path to eternal blessedness over another. This is the upshot of the many-gods objection. But what we find is that Pascal provides (to his own satisfaction) the very thing his critics find necessary. Charity, then, seems to require that our reading of Pascal's apology put the proofs prior to the wager.

But one should be skeptical of readings based solely on charity. As we briefly pointed out before, Pascal alludes to these proofs in the wager fragment itself. His libertine sees the strength of the wager but is hesitant to continue. "'But still . . . Is there no means of seeing what is in the cards?' Yes, Scripture and the rest, etc." (S680/L418). One might reasonably worry about the persuasive power of the wager if not for these proofs. If one questions whether the probability of Christianity being true is too low or lower than that of other religions, Pascal has a response, or rather several responses. Not only does prudential reasoning bear witness to the reasonability of belief in Christianity, but, by Pascal's lights, scripture and human nature also show us that it is likely true.

But according to Garber's reading of Pascal, we shouldn't expect these convincing proofs to be convincing prior to the regimen. Can they really belong before the wager? ${ }^{15}$ To see why they can, we need to look more closely at the nature of persuasion in Pascal. Pascal thinks that belief is not simply a matter of reason. "The way of God, who disposes all things kindly, is to implant religion into minds through reason and into hearts through grace" (S203/L172). Faith, the disposition of belief that Pascal is

\footnotetext{
${ }^{14}$ Fouke $(1989,58-60)$ describes these proofs in some detail, characterizing them as hypothetico-deductive proofs.

${ }^{15}$ We talk of order of reasons, not necessarily the ordering of the Pensées themselves. There is some uncertainty of Pascal's intended ordering of the fragments, when each fragment was written, which were abandoned, or even if the Pensées are intended to be one treatise or many. The order of reasons stands aside from all of these difficulties.
} 
directing his reader toward, is in the will; but since the will is not a faculty that can be merely redirected on a whim against one's own judgment, the question of belief becomes a matter of both reason and the will. Some who are already inclined toward belief may believe on the slightest evidence. For some, then, the wager will be superfluous.

The wager fragment (S680/L418) has a double role. It is intended to show us in its own way that belief is reasonable, but it also ends by calling us to initiate the regimen-doing what the believers have done-which is intended to have an effect on the will. It seems that the work on the reason and the work on the will are separable but often both necessary for the generation of belief. Why is the regimen necessary? It isn't due to any shortcoming in the arguments themselves, but rather due to the will's being badly disposed to belief via the interference of the passions.

This [the wager] is conclusive and if people are capable of any truth, this is it.

'I confess it, I admit it. But, still . . . Is there no means of seeing what is in the cards?' Yes, Scripture and the rest, etc. 'Yes, but my hands are tied and my mouth is shut; I am forced to wager, and am not free. I have not been released and I am made in such a way that I cannot believe. What, then, would you have me do?' That is true. But at least realize that your inability to believe comes from your passions, since reason brings you to this and yet you cannot believe. Work, then, on convincing yourself, not by adding more proofs of God's existence [note that it is assumed the proofs have already been presented], but by diminishing your passions. You would like to find faith and do not know the way? You would like to be cured of unbelief and ask for the remedies? Learn from those who were bound like you, and who now wager all they have. (S680/L418)

Pascal's libertine recognizes the reasonableness of belief and has all the information needed to form belief, but can't. It isn't because the proofs are faulty before the regimen. It is because the will is not disposed to follow reason where it leads. ${ }^{16}$

\section{Evaluation}

The wager as it appears in Pascal's apology is unobjectionable, at least in its immunity to existing criticisms. The many-gods objection cannot be raised since Pascal provides evidence for Christianity over other religions. The moral, intellectualist, and evidentialist objections cannot be raised because

\footnotetext{
${ }^{16}$ See James 1998 for a treatment of how the passions are both destructive and restorative in Pascal (1389-1391).
} 
the belief generated is not purely mercenary, but is a genuine belief based on reason. Garber's brainwashing objection can't be raised because, according to Pascal, different regimens would not produce different rational beliefs; it only strengthens those beliefs that reason has already accepted as more rational than other alternatives. The regimen's job isn't to show us evidence where we had previously saw none but to bring us to assent to what we've already recognized to be reasonable. ${ }^{17}$ In all these regards, if the apology fails, it isn't because of the wager. All the problems have been offloaded into the proofs. In the presence of non-demonstrative proofs or evidence, the wager adds yet another reason for belief. In the absence of convincing proofs, the wager fails.

It is worth noting that the mixed-strategies objection is a non-starter on this interpretation of the wager, even if it were to succeed before. Infinite utility's job in the previous versions of the wager is to make the probability of Christianity irrelevant so long as it's positive. Pascal notes this feature of infinite utility, but we have shown that he doesn't rely on it. Pascal thinks that "Scripture and the rest, etc." (S681/L418) shows us that the probability of Christianity is high enough to make belief reasonable. If we're bothered by this not being a demonstration, the wager puts those worries to rest. We have some high range of probability to assign to Christianity, so the infinity of the reward is a curiosity.

We have presented the wager three ways. As we read the wager in the context of Pascal's larger apologetic project, we find the wager to be unobjectionable, but we also find it to be relatively boring. Infinite utility plays no significant role. The reasonableness of an argument does not depend on custom (as developed in the regimen). Instead, the wager gives us a different kind of reason to believe-a prudential one-if we already have more ordinary reasons to believe. And if we find ourselves not responding to reason, Pascal prescribes the regimen to overcome whatever is blocking this proper response. How should we treat the wager then? Put simply, never on its own. If one desires to export it from Pascal's apology, one must replace his evidential arguments with others.

Joseph Anderson

E-mail : ander22j@cmich.edu

Daniel Collette

E-mail : dpaulcollette@gmail.com

References:

Clifford, William Kingdon. 1999. "The Ethics of Belief." In The Ethics of Belief and Other Essays. Translated by Tim Madigan. Amherst, N.Y.: Prometheus Books.

Duff, Antony. 1986. "Pascal's Wager and Infinite Utilities.” Analysis 46 (2): 107-109.

\footnotetext{
${ }^{17}$ Seeing the regimen in this light, it becomes clear that while there is a therapeutic aspect to it, it has epistemological implications. It seems that Pascal doesn't think just any regimen would result in evidence and belief. Pascal thinks his regimen will result in belief because it will remove the barriers (the passions) to appreciating evidence that is really there.
} 
Fouke, Daniel Clifford. 1989. “Argument in Pascal's Pensées.” History of Philosophy Quarterly 6 (1): 57-68.

Garber, Daniel. 2007. "Religio Philosophi." In Philosophers without Gods: Meditations on Atheism and the Secular Life, edited by Louise M. Antony, 32-40. Oxford: Oxford University Press.

Garber, Daniel. 2009. "What Happens after Pascal's Wager: Living Faith and Rational Belief.” In The Aquinas Lecture. Milwaukee, WI: Marquette University Press.

Hájek, Alan. 2003. "Waging War on Pascal's Wager." Philosophical Review 112 (1): 27-56.

Hunter, Graeme. 2013. Pascal the Philosopher: An Introduction. Toronto: University of Toronto Press.

James, Susan. 1998. "Reason, the Passions, and the Good Life." In The Cambridge History of Seventeenth-Century Philosophy: Volume II, edited by Daniel Garber and Michael Ayers, 1358-1397. New York: Cambridge University Press.

James, William. 1956. "The Will to Believe." In The Will to Believe and Other Essays in Popular Philosophy, 1-31. New York: Dover Publications.

Jordan, Jeff. 2006. Pascal's Wager: Pragmatic Arguments and Belief in God. Oxford: Oxford University Press.

Luhrmann, T. M. 1989. Persuasions of the Witch's Craft: Ritual Magic in Contemporary England. Cambridge, MA: Harvard University Press.

Morris, Thomas V. 1986. "Pascalian Wagering." Canadian Journal of Philosophy 16 (3): 437-454.

Pascal, Blaise. 1995. Pensées. Translated by A. J. Krailsheimer. New York: Penguin Books.

Pascal, Blaise. 2005. Pensées. Translated by Roger Ariew. Indianapolis, IN: Hackett Publishing Company.

Pascal, Blaise. 2011. Pensées: opuscules et lettres. Edited by Philip Sellier. Paris: Classiques Garnier.

Quinn, Phillip L. 1994. “Moral Objections to Pascalian Wagering.” In Gambling on God: Essays on Pascal's Wager, edited by Jeff Jordan, 61-82. Lanham, MD: Rowman \& Littlefield.

Wetsel, William David. 2009. "Blaise Pascal." In The History of Western Philosophy of Religion, edited by Graham Oppy and Nick Trakakis, Vol. 3, 127-140. Oxford: Oxford University Press. 